\title{
Interspecific Killing among Mammalian Carnivores
}

\author{
F. Palomares ${ }^{1, \star}$ and T. M. Caro ${ }^{2, \dagger}$
}

1. Department of Applied Biology, Estación Biológica de Doñana, CSIC, Avda. María Luisa s/n, 41013 Sevilla, Spain;

2. Department of Wildlife, Fish, and Conservation Biology and Center for Population Biology, University of California, Davis, California 95616

Submitted February 9, 1998; Accepted December 11, 1998

ABSTRACT: Interspecific killing among mammalian carnivores is common in nature and accounts for up to $68 \%$ of known mortalities in some species. Interactions may be symmetrical (both species kill each other) or asymmetrical (one species kills the other), and in some interactions adults of one species kill young but not adults of the other. There is a positive significant relationship between the body masses of solitary killer species and body masses of their victim species, and grouping species kill larger victims than solitary species. Interactions and consumption of the victim appear more common when food is scarce or disputed. In response to killers, victim species may alter their use of space, activity patterns, and form groups. Consequences of interspecific killing include population reduction or even extinction, and reduction and enhancement of prey populations, and may therefore have important implications for conservation and management of carnivores and their prey.

Keywords: carnivores, interspecific killing, intraguild predation, mesopredator release, population and community effects.

Direct (e.g., interference competition, predation) and indirect (e.g., exploitative competition, trophic cascades) interactions among species regulate natural populations and shape community structure (Case and Gilpin 1974; Estes and Palmisano 1974; Menge and Sutherland 1987; Paine et al. 1990; Bengtsson et al. 1994; Wootton 1994; Menge 1995). Despite great interest in such interactions, the actual influence of direct and indirect effects on food-web structure is still far from clear (Pianka 1988; Pimm 1991; Strauss 1991). This is especially true for food webs that include terrestrial mammalian carnivores, some of which are

* E-mail: ffpaloma@ebd03.ebd.csic.es.

† E-mail: tmcaro@ucdavis.edu.

Am. Nat. 1999. Vol. 153, pp. 492-508. (c) 1999 by The University of Chicago. 0003-0147/99/5305-0004\$03.00. All rights reserved. thought to act as keystone species in the top-down control of terrestrial ecosystems (Terborgh and Winter 1980; Terborgh 1992; McLaren and Peterson 1994). One factor affecting carnivore populations is interspecific killing by other carnivores (sometimes called intraguild predation; Polis et al. 1989), which has been hypothesized as having direct and indirect effects on population and community structure that may be more complex than the effects of either competition or predation alone (see, e.g., Latham 1952; Rosenzweig 1966; Mech 1970; Polis and Holt 1992; Holt and Polis 1997). Currently, there is renewed interest in intraguild predation from a conservation standpoint since top predator removal is thought to release other predator populations with consequences for lower trophic levels (termed "mesopredator release"; Soulé et al. 1988; Meffe et al. 1994).

In theory, interspecific killing might remove a source of mortality for the killer or its offspring (Eaton 1979) or free up food resources that would be consumed by the victim (Polis et al. 1989), or killers might accrue energetic benefits from consuming their victims, although victims generally feature little in the diet of their killers (discussed later). Unfortunately, however, we have no comprehensive knowledge of interspecific killing in carnivores, which impedes our understanding of its evolution, ecological importance, and conservation significance. Through a survey of published literature (see the appendix), we sought to document the distribution of interspecific killing among mammalian carnivores, to examine patterns of interactions, to determine whether consumption of victims occurs, to ascertain both direct and indirect effects on populations of victim species, and to identify implications for conservation and management.

\section{Distribution of Interspecific Killing}

Interspecific killing is common among mammalian carnivores. We uncovered 97 different pairwise interactions, involving 54 different victim and 27 killer species (table $1)$. The number of species killed was greater than the number of killer species for all families except felids. Figures in table 1 are conservative because we only considered cases in which there was unequivocal evidence that inter- 
Table 1: Interspecific killing among mammalian carnivores summarized by family

\begin{tabular}{lcccc}
\hline Family & $\begin{array}{c}\text { Number of interac- } \\
\text { tions where one } \\
\text { species was killed }\end{array}$ & $\begin{array}{c}\text { Number of } \\
\text { species killed }\end{array}$ & $\begin{array}{c}\text { Number of interac- } \\
\text { tions where a species } \\
\text { was the killer }\end{array}$ & $\begin{array}{c}\text { Number of } \\
\text { killer species }\end{array}$ \\
\hline Herpestids & 4 & $4(10.8)$ & $\ldots$ & $\ldots$ \\
Viverrids & 2 & $2(5.9)$ & $\ldots$ & $\ldots$ \\
Felids & 17 & $9(24.3)$ & 47 & $12(32.4)$ \\
Hyaenids & 5 & $3(75.0)$ & 7 & $2(50.0)$ \\
Ursids & 5 & $4(44.4)$ & 4 & $2(22.2)$ \\
Canids & 37 & $14(40.0)$ & 34 & $\ldots$ \\
Procyonids & 2 & $1(5.6)$ & 0 & $3(4.8)$ \\
Mustelids & 25 & $17(27.0)$ & 5 & $27(11.4)$ \\
\multicolumn{1}{c}{ Total } & 97 & $54(22.8)$ & 97 & $\ldots$ \\
\hline
\end{tabular}

Note: Parentheses refer to the percentage of species in the family, following Wozencraft (1989).

actions led to the death of an individual (i.e., direct observations of encounters or dead animals with clear evidence of having been killed by another mammalian carnivore species). Although data on carnivore diets also point to numerous instances of carnivores being prey (e.g., see Rosenzweig 1966 and Erlinge 1981 for some mustelid species; Mills 1990 for brown hyena Hyaena brunnea; and Bailey 1993 for leopard Panthera pardus), these could represent carrion feeding. Therefore, information from dietary studies was not considered here. We also excluded instances in which a domestic species was the killer because domestic species may have been trained to kill other species (e.g., Canis familiaris).

Canids, mustelids, and felids (as victim) and felids and canids (as killer) were the families most involved in the interactions (table 1). The species that were most often victims were the red fox in seven pairwise interactions; domestic dog in five; bat-eared fox Otocyon megalotis in four; and African wild dog Lycaon pictus, cheetah Acinonyx jubatus, the arctic fox Alopex lagopus, American marten Martes americana, and lion each in three pairwise interactions. Regarding killer species, those of the genera Panthera and Lynx were in $79 \%$ of the pairwise interactions involving felid species $(n=47)$, with the leopard, the lion Panthera leo, the Eurasian lynx Lynx lynx, and the Spanish lynx Lynx pardinus, being the most important killers accounting for 13, nine, six, and six pairwise interactions, respectively. Species of genus Canis and Vulpes accounted for $85 \%$ of interactions that involved any canid species being the killer $(n=34)$. The gray wolf Canis lupus, with 12, the red fox Vulpes vulpes, with nine, and the coyote Canis latrans, with eight, are the species most often cited as killers.

The families least recorded as either killing other carnivores or being killed (herpestids, viverrids, and procyonids; table 1) are those that have received little study. In addition, these families include small and medium-sized species, which reduces the likelihood of finding their remains or even the remains of species killed by them as their victims are small (discussed later). In fact, of the 27 killer species, $37.0 \%$ are heavier than $50 \mathrm{~kg}, 44.4 \%$ lie between 10 and $50 \mathrm{~kg}$, and only $18.5 \%$ are smaller than $10 \mathrm{~kg}$. For victims, the figures are $16.7 \%, 25.9 \%$, and $57.4 \%$, respectively.

\section{Patterns of Interaction}

Age, size, and patterns of grouping play a significant role in the outcome of interactions between mammalian carnivores. Smaller species may kill cubs, young, or subadult individuals of the larger species (fig. 1A; four of seven instances; see the appendix), but in general, larger species usually kill both adult and juvenile individuals of the smaller species (fig. 1B; 24 of 26 instances; see the appendix). One of the two exceptions to the latter finding was two records of wolves killing adult black bears Ursus americanus (Rogers and Mech 1981; Paquet and Carbyn 1986). In both instances, the wolves were in packs (see later discussion). Mutual killings have also been recorded (see the appendix). Some interacting species are able to kill only nonadults of the other (fig. 1C; e.g., red foxes and European badgers Meles meles), one species kills both adults and nonadults of the second, whereas the second kills only nonadults of the first species (fig. $1 D$; e.g., lions and spotted hyenas Crocuta crocuta and lions and leopards), or both species kill both adults and nonadults of the other (fig. 1E; e.g., lions and African wild dogs or Asian wild dogs Cuon alpinus and tigers Panthera tigris). In the last two cases, grouping has an important role in the final result of the interaction (see Eaton 1979).

Relative body mass of interactants (i.e., mass of victim/ mass of killer) is significantly higher for species killed by carnivores that group than for solitary species $(N=6$, mean $=3.84 \pm 1.85 \mathrm{SE}$ vs. $N=9$, mean $=0.47 \pm 0.10$, 
(A)

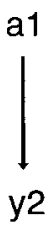

(B)

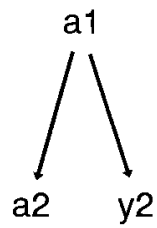

(D)

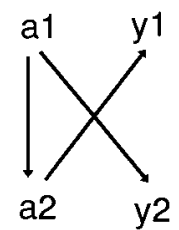

(C)

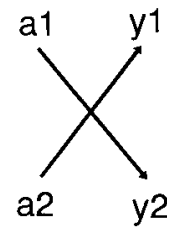

(E)

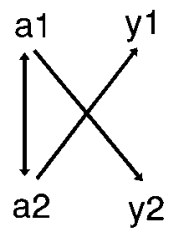

Figure 1: Patterns of interspecific killing in mammalian carnivores. Numbers denote species; letters denote adult $(a)$ and nonadult $(y)$ individuals. Arrows indicate direction from killer to victim. Asymmetrical age-structured patterns arise when species 1 may kill either $(A)$ only nonadults or $(B)$ both age classes of species 2. Mutual killings exist in which $(C)$ both species kill nonadults of the other, $(D)$ species 1 kills both adults and nonadults of species 2, but species 2 can only kill nonadults of species 1 , and $(E)$ both species kill each age class of the other.

respectively; $t=2.27, \mathrm{df}=13, P=.041$; fig. 2). Indeed, carnivores that group can kill species that weigh up to 12 times their own body mass (fig. 2), similar to that found for prey (Earle 1987). Only in the case of brown bears Ursus arctos killing black bears has a solitary carnivore been recorded as killing a potentially heavier carnivore. The records, however, were of an adult brown bear killing cubs of black bears (Ross et al. 1988) or an adult male brown bear (ca. 190-200 kg) killing adult female black bears (ca. 98-99 kg; Mattson et al. 1992; Smith and Follmann 1993). Therefore, heavier individuals also killed smaller individuals in these cases. Moreover, mass of bears varies considerably between populations (e.g., see Nowak 1991).

Figure 2 shows that the weight of victim increases with weight of solitary killers (log weight of victim $=$ $-0.065+0.731 \times \log$ weight of killer, adj. $R^{2}=0.66$, $F=16.78, P=.0046$, using the heaviest species killed by each of the eight solitary killers known to kill adults of other species and the actual weights of the interacting bears of the killings reported by Mattson et al. [1992] and Smith and Follmann [1993]). For solitary species, there seems to be a threshold above which the victim cannot be killed. For example, in southwestern Spain the Spanish lynx kills 2-7-kg species, such as the European genet Genetta genetta, Egyptian mongoose Herpestes ichneumon, red fox, and domestic cat, but not badgers that weigh between 7 and $9 \mathrm{~kg}$ (Palomares et al. 1996).

\section{Consumption of Victims}

Some carnivores consume their victims. Of 21 killer species where information was available, killers always totally or partially ate their victims in 10 cases, either did or did not eat them in eight cases, or never ate them in three (see the appendix). There are no clear taxonomic or behavioral patterns to these data except that all consumers have been reported as feeding on carrion. Characteristics of the victims did not seem to affect consumption, as the same species was sometimes eaten but at other times was not, either by the same or different killer species (e.g., killed cheetahs, coyotes, red foxes, domestic dogs, kit foxes Vulpes macrotis, bat-eared foxes, stoats Mustela erminea, and European pine martens Martes martes).

Availability of alternative prey may be a determinant of both interspecific killing and consumption (Macdonald 1977; Polis 1981; Ackerman et al. 1984; Stephenson et al. 1991) as the diets of sympatric carnivores often show great overlap (e.g., see Kruuk 1972; Delibes 1980; Major and Sherburne 1987; Lindström 1989; Smits et al. 1989; Theberge and Wedeles 1989; Paquet 1992; Mills and Biggs 1993; Palomares 1993; Karanth and Sunquist 1995; Okarma 1995, Okarma et al. 1997). For example, Ballard (1982) found that the number of kills contested by wolves and bears was higher in areas of low prey density. In 36 cases, authors of carnivore studies in northern latitudes

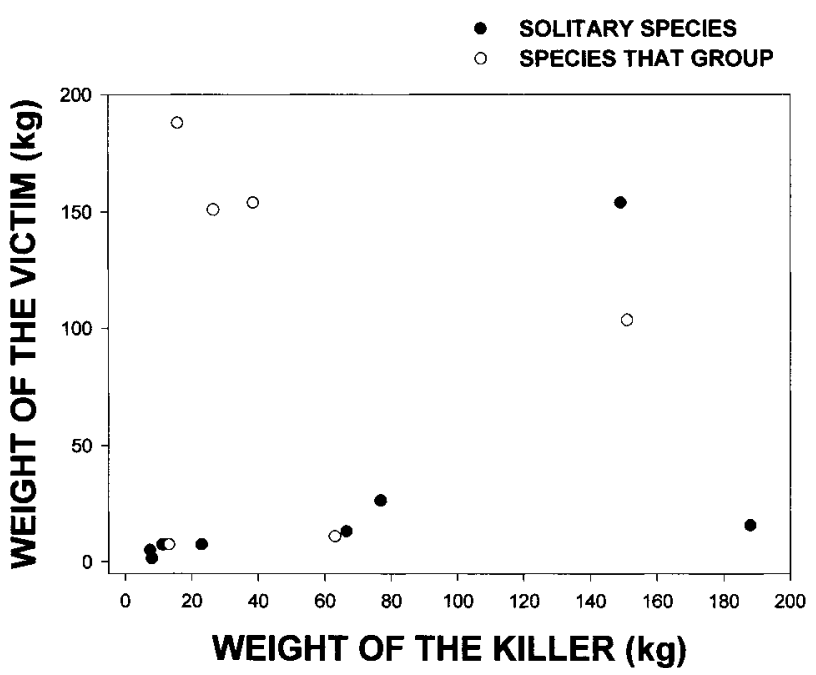

Figure 2: Body mass of victims plotted against body mass of killers. For killers, solitary species are filled circles, and group living species are open circles. When more than one data set was available for a given killer species, only data of the heaviest victim are shown. 
Table 2: Extent of mortality resulting from interspecific killing in mammalian carnivores

\begin{tabular}{|c|c|c|c|c|}
\hline Species killed & $\begin{array}{l}\text { Percentage of } \\
\text { mortalities }\end{array}$ & Killer species & Region & Sources \\
\hline African wild dog & $13-50$ & Lion, spotted hyena & $\begin{array}{l}\text { Botswana, South Af- } \\
\text { rica, Tanzania }\end{array}$ & $\begin{array}{l}\text { Mills and Biggs 1993; } \\
\text { Creel and Creel } \\
\text { 1996, } 1998\end{array}$ \\
\hline American marten & 4 & Red fox & Ontario & Thompson 1994 \\
\hline Black-footed ferret & $33^{\mathrm{a}}$ & Coyote & Wyoming & Forrest et al. 1988 \\
\hline Bobcat & $12^{\mathrm{a}}-62$ & Coyote, cougar & Idaho & $\begin{array}{l}\text { Knick 1990; Koehler } \\
\text { and Hornocker } \\
1991\end{array}$ \\
\hline Cheetah & $68^{\mathrm{b}}$ & $\begin{array}{l}\text { Lion, spotted hyena, } \\
\text { leopard }\end{array}$ & Tanzania & Laurenson 1994, 1995 \\
\hline Coyote & $43-67^{\mathrm{a}}$ & Cougar, wolf & Alaska, Idaho & $\begin{array}{l}\text { Koehler and Hor- } \\
\text { nocker 1991; } \\
\text { Thurber et al. } 1992\end{array}$ \\
\hline Egyptian mongoose & $0-67^{a}$ & Spanish lynx & Spain & $\begin{array}{l}\text { Palomares and De- } \\
\text { libes 1992; F. Palo- } \\
\text { mares, unpublished } \\
\text { data }\end{array}$ \\
\hline European badger & $9^{a}$ & Red fox & Spain & $\begin{array}{l}\text { E. Revilla, unpub- } \\
\text { lished data }\end{array}$ \\
\hline European genet & $33^{\mathrm{a}}$ & Spanish lynx & Spain & $\begin{array}{l}\text { Palomares and De- } \\
\text { libes } 1994\end{array}$ \\
\hline Kit fox & $50-76^{\mathrm{a}}$ & Coyote, red fox & California & $\begin{array}{l}\text { O'Farrell 1984; Ralls } \\
\text { and White 1995; } \\
\text { Cypher and Spen- } \\
\text { cer } 1998\end{array}$ \\
\hline Lion & $8^{\mathrm{b}}$ & Leopard, hyena & Serengeti & Schaller 1972 \\
\hline European pine marten & $50^{\mathrm{a}}$ & Red fox & Scandinavia & Lindström et al. 1995 \\
\hline Raccoon & $11^{\mathrm{a}}$ & Coyote & Iowa & Judson et al. 1994 \\
\hline Red fox & $13^{\mathrm{a}}$ & Spanish lynx & Spain & $\begin{array}{l}\text { F. Palomares et al., } \\
\text { unpublished data }\end{array}$ \\
\hline Spotted hyena & 55 & Lion & Serengeti & Kruuk 1972 \\
\hline Striped skunk & 22 and $17^{\mathrm{a}, \mathrm{c}}$ & American badger & North Dakota & Sargeant et al. 1982 \\
\hline Swift fox & $45^{\mathrm{a}}$ & $\begin{array}{l}\text { Coyote, North Ameri- } \\
\text { can badger }\end{array}$ & Alberta & Carbyn et al. 1994 \\
\hline
\end{tabular}

reported the date of carnivore interactions. Twenty-four $(67 \%)$ took place during the cold season (November-March) when prey is less available, which suggests that competition over food may have been important, although tracking carnivores in snow may have inflated this figure. Regarding consumption, Boyd and O'Gara (1985) report a coyote killed but not consumed by a cougar Felis concolor, near a prey carcass but four other coyotes killed by cougars away from carcasses that were eaten. Also, while defending or usurping food caches, cougars killed coyotes and bobcats Felis rufus but did not eat them, perhaps because alternative food was on hand (Koehler and Hornocker 1991).

\section{Direct Effects of Interspecific Killing on Victim Populations}

Mortality resulting from interspecific killing can be high, ranging from $43 \%$ to $68 \%$ of mortalities, as, for example, in cheetah, bobcat, spotted hyena, African wild dog, coyote, European pine marten, kit fox, or Egyptian mongoose (table 2); arctic fox populations on islands or at the limits of their distribution may even be extirpated by red foxes (Bailey 1992; Hersteinsson and Macdonald 1992). Two of five radio-tracked common palm civets Paradoxurus hermaphroditus were also killed by undetermined carnivores in Nepal (Joshi et al. 1995). Negative relationships exist 
between densities of cheetahs and both lions and spotted hyenas, densities of African wild dogs and both lions and spotted hyenas, and Egyptian mongooses and Spanish lynx (Laurenson 1995; Creel and Creel 1996; Palomares et al. 1998). In each case, interspecific killing between pairs of these species has been witnessed repeatedly. Furthermore, Laurenson (1995), Lindström et al. (1995), Olsson et al. (1997), and White and Garrott (1997) suggest, respectively, that interspecific killing may be limiting the population density of cheetahs by lions in the Serengeti; European pine marten and European badgers by red foxes and wolves, respectively, in Scandinavia; and kit foxes by coyotes in North America.

More circumstantial evidence suggests that populations of weasels, stoats, North American badgers Taxidea taxus, leopards, coyotes, red foxes, wolverine Gulo gulo, raccoons Procyon lotor, and brown bears may all be reduced through interspecific killing (Latham 1952; Robinson 1953; Pulliainen 1965; Schaller 1967; Mech 1970; Linhart and Robinson 1972; Carbyn 1982; Erlinge et al. 1982; Dekker 1989; Johnson et al. 1989; Stephenson et al. 1991; Thurber et al. 1992). Nevertheless, there are many studies in which interspecific killing occurs only infrequently. Here, species may be avoiding each other (see later discussion), such as black bears avoiding brown bears (Miller et al. 1997) or cheetahs avoiding lions (Durant 1998), or, alternatively, rates of killing may actually be low, as in the case of red foxes that share dens with European badgers in which only a few instances have been noted despite intensive study (Neal and Cheeseman 1996).

\section{Indirect Effects of Interspecific Killing on Victim Populations}

\section{Shifts in Space Use}

Victim species may occupy areas that do not overlap with the killer species' home ranges, or they may use different habitats. Red foxes have been reported as using the periphery of coyote home ranges or different habitats from coyotes where they occur sympatrically, and coyotes have been noted as using areas between wolf home ranges (Fuller and Keith 1981; Voigt and Earle 1983; Major and Sherburne 1987; Sargeant et al. 1987; Dekker 1989; Harrison et al. 1989; Theberge and Wedeles 1989; Thurber et al. 1992). European genets and Egyptian mongooses avoid suitable habitats where densities of Spanish lynx are high (Palomares et al. 1996), as do wild dogs and cheetahs where lions are common (Mills and Gorman 1997; Durant 1998). Predator avoidance apparently increases fitness at least in one species. Female cheetah lifetime reproductive success was significantly negatively correlated with the proportion of cheetah family sightings in which lions were close by
(Kelly et al. 1998), and individual females that respond quicker to playbacks of lions and spotted hyenas had higher reproductive success (S. M. Durant, unpublished data). Other mechanisms to avoid being killed include the use of a large number of dens as may occur in California kit foxes (White et al. 1994).

\section{Temporal Segregation}

Victims may adjust their activity patterns to reduce encounters with killer species (Litvaitis 1992; Johnson et al. 1996) although evidence for this is circumstantial. In Kruger National Park, lions hunt mainly at night, wild dogs in early morning, and cheetahs around the middle of the day (Mills and Biggs 1993). Although cheetahs hunt during the hottest period, it may help them reduce kleptoparasitism and interference from lions and spotted hyenas (Schaller 1972). Rudzinski et al. (1982) attempted to evaluate interactions between red and arctic foxes by conducting trials in enclosures. Rarely were both species active simultaneously, and activity of arctic foxes decreased when red foxes were present. Nevertheless, clear temporal segregation has been found rarely in studies of resource partitioning between sympatric potentially interacting carnivores (e.g., Major and Sherburne 1987; Litvaitis and Harrison 1989).

\section{Group Formation}

Grouping allows medium and small-sized carnivores to obtain antipredator advantages or compete more successfully for food (Kruuk 1975; Eaton 1979; Lamprecht 1981; Gittleman 1989). It has been shown (Caro 1994) that adolescent cheetahs in groups were more effective at deterring spotted hyenas than singleton adolescents. After hypothesized benefits of group hunting were excluded, it was concluded that antipredator benefits were the principal factor favoring litter mates' temporary associations following independence. Dwarf mongooses Helogale parvula, experienced lower predation rates with increased group size (Rasa 1986). G. Koehler (unpublished data) observed a group of three coyotes mobbing and successfully chasing a cougar.

Most African carnivores that form groups successfully defend prey more often than solitary individuals (Kruuk 1972; Schaller 1972; Fanshawe and FitzGibbon 1993; Mills 1993). For instance, Carbone et al. (1997) demonstrated that wild dogs hunting in small groups (one to two individuals) would be particularly vulnerable to kleptoparasitism by spotted hyenas, whereas intermediate-sized groups may be most effective at meeting nutritional demands. Also, in North America, large packs of coyotes 
successfully defend carcasses against cougars and bears in Yellowstone National Park (D. Boyd, unpublished data).

\section{Changes in Prey Populations}

For some time, it has been surmised that when the killer species disappears from an area, smaller predators may be released, which places additional pressure on prey populations. As illustrations, the extinction or decline of many bird species on Barro Colorado Island (Terborgh and Winter 1980), in eastern North America (Sargeant et al. 1984; Wilcove 1985), and in southeastern Spain (Suárez et al. 1993) was inferred as being due to mesopredator release owing to the absence of top carnivores. A few studies have quantified the effect of large carnivore presence on populations of prey. For example, Soulé et al. (1988) showed that presence or absence of coyotes affected the abundance of smaller carnivores such as gray foxes Urocyon cineroargenteus and feral cats Felis domesticus in canyons around San Diego. These in turn affected the abundance of birds so that in the absence of coyotes, the number of bird species was depressed. Sovada et al. (1995) studied duck nesting success in upland areas of North America where coyotes or red foxes occurred and found that nesting success was higher in areas dominated by coyotes. In southwestern Spain, high densities of the Spanish lynx may benefit European rabbits Oryctolagus cuniculus by controlling Egyptian mongooses that also feed on rabbits (Palomares et al. 1995). Although these three studies reached their conclusions based on known interactions among predator species, other explanations such as alteration of natural habitats or human presence need to be excluded (Wright et al. 1994; Litvaitis and Villafuerte 1996).

\section{Implications for Conservation}

Some endangered species such as cheetah and wild dog suffer consequences of interactions with larger carnivores that in certain areas have increased owing to protection policies (Caro and Laurenson 1994; Creel and Creel 1996; Gorman et al. 1998; Kelly et al. 1998). Also, reintroductions of the endangered swift fox Vulpes velox and blackfooted ferret Mustela nigripes in North America have been jeopardized by coyote predation (Carbyn et al. 1994; S. Forrest, unpublished data). Solutions to these conservation problems are difficult because reduction of larger predators is distasteful. In situations in which they have been proposed (Forrest et al. 1985), managers must be given detailed knowledge of killer species' diets before implementing any program of biological control (Schmidt 1985; Waage and Mills 1992).

Protection of larger carnivores may play an important role in the control of less desirable species. By conserving the Spanish lynx, the negative impact of red foxes and Egyptian mongooses on small game populations can be ameliorated (Palomares et al. 1995). Similarly, protecting coyotes may reduce the effect of red foxes on ducks in North America (Sargeant et al. 1984; Sovada et al. 1995) because foxes can be killed by coyotes. Managing certain carnivores may therefore be a low-cost and effective method for increasing abundance of some prey species. Furthermore, knowledge of the importance of dominant predators and their positive indirect effects on prey of concern may provide a basis for the conservation of some threatened species (as in Spanish lynx; Nowell and Jackson 1996), which otherwise might be viewed as being in conflict with game management objectives.

\section{Conclusions}

Interspecific killing appears common in communities of mammalian carnivores of North America, Africa, and Europe, although ecological and behavioral factors affecting it are poorly understood. Further study of interspecific killing between more pairs of species and in different environments should provide insights as to whether lifehistory characteristics and productivity of an area affect intensity of the interactions and consumption of victims.

To understand the consequences of interspecific killing in mammalian carnivores, we need quantitative data on carnivore and prey populations. For example, theoretical models of intraguild predation suggest that predator coexistence arises when the victim species is superior at exploitative competition for a shared resource, but the killer species gains significantly from the consumption of the victim. At present, however, interspecific interactions have been revealed through qualitative rather than quantitative measures, and future efforts should be directed in determining to what extent various densities of a given species alter abundance or behavior of the other. Realistically, the feasibility of gaining such knowledge in mammalian carnivores is low because they are scarce, difficult to see and to catch, move over large areas, and may be threatened. Natural experiments, large-scale environmental management decisions, together with the long-term monitoring of communities or the selection of suitable ecologically similar areas for comparison, are perhaps the only ways of inferring the ecological consequences of killing among mammalian carnivores (Diamond 1986; Sarrazin and Barbault 1996; also see Bender et al. 1984). Such information is nevertheless essential to construct explanatory, semiquantitative theories of ecological communities. 


\section{Acknowledgments}

The research was supported by Dirección General de Investigación Científica y Técnica (project PB94-0480). We thank H. Andrén, A. Angerbjörn, D. Boyd, W. R. Clark, S. Creel, M. Delibes, S. Durant, J. M. Fedriani, P. Ferreras,
S. Forrest, K. Frafjord, J. O. Helldin, S. Knick, G. M. Koehler, H. Kruuk, T. Kvam, J. A. Litvaitis, D. S. Maehr, S. Minta, D. Monson, H. Okarma, K. Ralls, E. Revilla, A. Rodríguez, I. Thompson, and three anonymous referees for making helpful comments and for providing additional references and unpublished information. 


\section{APPENDIX}

Table A1: Instances of interspecific killing among mammalian carnivores

\begin{tabular}{|c|c|c|c|c|}
\hline Killed species & Killer species & $\begin{array}{l}\text { Age class } \\
\text { of victim }\end{array}$ & $\begin{array}{l}\text { Consumption } \\
\text { of victim }\end{array}$ & Sources \\
\hline $\begin{array}{l}\text { Acinonyx jubatus } \\
\text { (cheetah) }\end{array}$ & $\begin{array}{l}\text { Crocuta crocuta (spotted } \\
\text { hyena) }\end{array}$ & a & $\mathrm{C}$ & Laurenson 1995 \\
\hline A. jubatus & Panthera leo (lion) & $\mathrm{b}$ & NC & $\begin{array}{l}\text { Schaller 1972; Laurenson } \\
\quad \text { 1994, } 1995\end{array}$ \\
\hline A. jubatus & $\begin{array}{l}\text { Panthera pardus } \\
\quad \text { (leopard) }\end{array}$ & a & SC & $\begin{array}{l}\text { Kruuk and Turner 1967; } \\
\text { Schaller 1972; Mills } \\
\text { 1990; Laurenson } 1995\end{array}$ \\
\hline $\begin{array}{l}\text { Ailurus fulgens } \\
\text { (red panda) }\end{array}$ & P. pardus & $\mathrm{b}$ & $\cdots$ & Yonzon and Hunter 1991 \\
\hline $\begin{array}{l}\text { Alopex lagopus } \\
\text { (Arctic fox) }\end{array}$ & $\begin{array}{l}\text { Ursus maritimus (polar } \\
\text { bear) }\end{array}$ & $\cdots$ & $\cdots$ & Chesemore 1975 \\
\hline A. lagopus & Vulpes vulpes (red fox) & $\mathrm{b}$ & $\cdots$ & $\begin{array}{l}\text { Frafjord et al. 1989; Tan- } \\
\text { nerfeldt 1997; A. An- } \\
\text { gerbjön, unpublished } \\
\text { data; J. Linnell, un- } \\
\text { published data }\end{array}$ \\
\hline A. lagopus & Gulo gulo (wolverine) & $\cdots$ & $\ldots$ & Tannerfeldt 1997 \\
\hline $\begin{array}{l}\text { Canis aureus } \\
\quad \text { (golden jackal) }\end{array}$ & C. crocuta & $\mathrm{b}$ & $\mathrm{NC}$ & Kruuk 1972 \\
\hline $\begin{array}{l}\text { Canis familiaris } \\
\quad \text { (domestic dog) }\end{array}$ & Canis latrans (coyote) & $\ldots$ & $\mathrm{C}$ & Bider and Weil 1984 \\
\hline C. familiaris & Canis lupus (gray wolf) & $\mathrm{b}$ & (C) & $\begin{array}{l}\text { Fritts and Paul 1989; J. } \\
\text { Linnell, unpublished } \\
\text { data }\end{array}$ \\
\hline C. familiaris & $\begin{array}{l}\text { Lynx pardinus (Spanish } \\
\text { lynx) }\end{array}$ & $\cdots$ & $\cdots$ & Valverde 1967 \\
\hline C. familiaris & Lynx lynx (Eurasian lynx) & $\cdots$ & $\mathrm{C}$ & Okarma et al. 1997 \\
\hline C. familiaris & $P$. pardus & $\cdots$ & $\mathrm{C}$ & $\begin{array}{l}\text { Seidensticker et al. 1990; } \\
\text { Johnsingh } 1992\end{array}$ \\
\hline C. latrans & C. lupus & $\mathrm{b}$ & (C) & $\begin{array}{l}\text { Berg and Chesness 1978; } \\
\text { Carbyn 1982; Paquet } \\
\text { 1991; Thurber et al. } \\
\text { 1992; Boyd et al. } 1994\end{array}$ \\
\hline C. latrans & $\begin{array}{l}\text { Felis concolor (mountain } \\
\quad \text { lion) }\end{array}$ & $\mathrm{b}$ & (C) & $\begin{array}{l}\text { Ackerman et al. 1984; } \\
\text { Boyd and O'Gara } \\
\text { 1985; Koehler and } \\
\text { Hornocker } 1991\end{array}$ \\
\hline C. lupus & $\begin{array}{l}\text { Ursus arctos (brown } \\
\text { bear) }\end{array}$ & $\mathrm{b}$ & (C) & $\begin{array}{l}\text { Ballard 1980; Hayes and } \\
\text { Baer 1992; S. Minta, } \\
\text { unpublished data }\end{array}$ \\
\hline $\begin{array}{l}\text { Canis mesomelas } \\
\text { (black-backed } \\
\text { jackal) }\end{array}$ & P. pardus & $\cdots$ & $\mathrm{C}$ & $\begin{array}{l}\text { Kruuk and Turner 1967; } \\
\quad \text { Mills } 1990\end{array}$ \\
\hline $\begin{array}{l}\text { C. mesomelas } \\
\text { Civettictis civetta }\end{array}$ & P. leo & $\ldots$ & NC & Stander 1992 \\
\hline (African civet) & P. pardus & $\cdots$ & $\mathrm{C}$ & Bailey 1993 \\
\hline C. crocuta & P. leo & $\mathrm{b}$ & NC & $\begin{array}{l}\text { Kruuk 1972; Eloff 1984; } \\
\quad \text { Mills } 1990\end{array}$ \\
\hline $\begin{array}{l}\text { C. crocuta } \\
\text { Cuon alpinus }\end{array}$ & P. pardus & $\mathrm{a}$ & $\mathrm{C}$ & Bailey 1993 \\
\hline (dhole) & Panthera tigris (tiger) & $\mathrm{b}$ & $\ldots$ & Schaller 1967 \\
\hline
\end{tabular}


Table A1 (Continued)

\begin{tabular}{|c|c|c|c|c|}
\hline Killed species & Killer species & $\begin{array}{l}\text { Age class } \\
\text { of victim }\end{array}$ & $\begin{array}{l}\text { Consumption } \\
\text { of victim }\end{array}$ & Sources \\
\hline C. alpinus & P. pardus & $\cdots$ & $\mathrm{C}$ & Johnsingh 1992 \\
\hline \multicolumn{5}{|l|}{ Cynictis penicillata (yel- } \\
\hline low mongoose) & $\begin{array}{l}\text { Felis caracal } \\
\quad \text { (caracal) }\end{array}$ & $\cdots$ & $\cdots$ & Cavallini 1993 \\
\hline Enhydra lutris (sea otter) & U. arctos & $\cdots$ & $\mathrm{C}$ & Monson and DeGange 1995 \\
\hline Felis catus (domestic cat) & L. pardinus & $\mathrm{b}$ & NC & Palomares et al. 1996 \\
\hline F. catus & L. $\operatorname{lyn} x$ & $\ldots$ & $\ldots$ & Liberg 1997 \\
\hline F. concolor & C. lupus & $\mathrm{a}$ & (C) & $\begin{array}{l}\text { White and Boyd 1989; } \\
\text { Boyd and Neale 1992; } \\
\text { Boyd et al. } 1994\end{array}$ \\
\hline \multicolumn{5}{|l|}{ Felis libyca (African wild } \\
\hline cat) & F. caracal & $\ldots$ & $\ldots$ & Mills 1990 \\
\hline F. libyca & P. pardus & $\ldots$ & $\mathrm{C}$ & Mills 1990 \\
\hline Felis pardalis (ocelot) & $\begin{array}{l}\text { Panthera onca } \\
\quad \text { (jaguar) }\end{array}$ & $\cdots$ & $\ldots$ & $\begin{array}{l}\text { Mondolfi and Hoogesteijn } \\
1986\end{array}$ \\
\hline Felis rufus (bobcat) & F. concolor & $\ldots$ & NC & $\begin{array}{l}\text { Koehler and Hornocker } \\
1991\end{array}$ \\
\hline F. rufus & C. latrans & $\mathrm{b}$ & $\ldots$ & Knick 1990 \\
\hline \multicolumn{5}{|l|}{ Genetta genetta (Euro- } \\
\hline pean genet) & L. pardinus & $\mathrm{b}$ & NC & $\begin{array}{l}\text { Palomares et al. 1996; F. } \\
\text { Palomares, unpublished } \\
\text { data }\end{array}$ \\
\hline G. gulo & C. lupus & $\mathrm{b}$ & NC & $\begin{array}{l}\text { Burkholder 1962; Boles } \\
1977\end{array}$ \\
\hline \multicolumn{5}{|l|}{ Helogale parvula (dwarf } \\
\hline \multicolumn{5}{|l|}{ Herpestes ichneumon } \\
\hline (Egyptian mongoose) & L. pardinus & $\mathrm{b}$ & NC & $\begin{array}{l}\text { Palomares et al. 1996; F. } \\
\text { Palomares, unpublished } \\
\text { data }\end{array}$ \\
\hline \multicolumn{5}{|l|}{ Hyaena brunnea (brown } \\
\hline hyena) & C. crocuta & ... & $\ldots$ & Mills 1990 \\
\hline H. brunnea & P. leo & $\ldots$ & NC & Eloff 1984; Mills 1990 \\
\hline \multicolumn{5}{|l|}{ Ictonyx striatus (striped } \\
\hline \multicolumn{5}{|l|}{ Lutra canadensis (river } \\
\hline \multicolumn{5}{|l|}{ Lutra lutra (European } \\
\hline otter) & L. pardinus & $\ldots$ & $\ldots$ & Valverde 1967 \\
\hline L. lutra & L. $\operatorname{lyn} x$ & $\ldots$ & $\ldots$ & Liberg 1997 \\
\hline \multicolumn{5}{|l|}{ Lycaon pictus (African } \\
\hline hunting dog) & C. crocuta & a & $\mathrm{C}$ & $\begin{array}{l}\text { Creel et al. 1995; Ginsberg } \\
\text { et al. } 1995\end{array}$ \\
\hline L. pictus & P. leo & $\mathrm{b}$ & NC & $\begin{array}{l}\text { Mills and Biggs 1993; Creel } \\
\text { and Creel } 1996\end{array}$ \\
\hline L. pictus & P. pardus & $\mathrm{b}$ & $\ldots$ & S. Creel, unpublished data \\
\hline $\begin{array}{l}\text { Martes americana } \\
\text { (American or pine } \\
\text { marten) }\end{array}$ & V. vulpes & b & $\cdots$ & Thompson 1994 \\
\hline M. americana & C. lupus & $\mathrm{b}$ & $\ldots$ & Paragi et al. 1996 \\
\hline M. americana & $\begin{array}{l}\text { Martes pennanti } \\
\quad \text { (Fisher) }\end{array}$ & .. & $\cdots$ & Raine 1983 \\
\hline
\end{tabular}


Table A1 (Continued)

\begin{tabular}{|c|c|c|c|c|}
\hline Killed species & Killer species & $\begin{array}{l}\text { Age class } \\
\text { of victim }\end{array}$ & $\begin{array}{l}\text { Consumption } \\
\text { of victim }\end{array}$ & Sources \\
\hline $\begin{array}{l}\text { Martes martes (Euro- } \\
\text { pean pine marten) }\end{array}$ & V. vulpes & $\mathrm{b}$ & $\mathrm{NC}$ & Lindström et al. 1995 \\
\hline M. martes & L. $\operatorname{lyn} x$ & $\mathrm{~b}$ & $\mathrm{C}$ & $\begin{array}{l}\text { Okarma et al. 1997; H. } \\
\text { Okarma, unpublished } \\
\text { data; J. Linnell, unpub- } \\
\text { lished data }\end{array}$ \\
\hline \multicolumn{5}{|l|}{ Meles meles (Eurasian } \\
\hline badger) & V. vulpes & a & NC & $\begin{array}{l}\text { Neal and Cheeseman } \\
\text { 1996; E. Revilla, un- } \\
\text { published data }\end{array}$ \\
\hline \multicolumn{5}{|l|}{ Mellivora capensis } \\
\hline (ratel) & P. leo & $\cdots$ & $\mathrm{NC}$ & Eloff 1984 \\
\hline \multicolumn{5}{|l|}{ Mephitis mephitis } \\
\hline (striped skunk) & C. lupus & ... & $\mathrm{C}$ & $\begin{array}{l}\text { Boyd et al. 1994; D. Boyd, } \\
\text { unpublished data }\end{array}$ \\
\hline M. mephitis & $\begin{array}{l}\text { Taxidea taxus (North } \\
\text { American badger) }\end{array}$ & $\mathrm{b}$ & $\mathrm{NC}$ & $\begin{array}{l}\text { Sargeant et al. 1982; Ro- } \\
\quad \text { satte } 1987\end{array}$ \\
\hline \multicolumn{5}{|l|}{ Mustela erminea } \\
\hline (stoat) & A. lagopus & .. & $\mathrm{C}$ & $\begin{array}{l}\text { K. Frafjord, unpublished } \\
\text { data }\end{array}$ \\
\hline M. erminea & V. vulpes & $\ldots$ & NC & Mulder 1990 \\
\hline \multicolumn{5}{|l|}{ Mustela frenata (long- } \\
\hline tailed weasel) & $\begin{array}{l}\text { Urocyon cineroargenteus } \\
\quad \text { (gray fox) }\end{array}$ & $\cdots$ & $\cdots$ & Latham 1952 \\
\hline M. frenata & V. vulpes & $\ldots$ & NC & Latham 1952 \\
\hline \multicolumn{5}{|l|}{ Mustela nigripes } \\
\hline (black-footed ferret) & C. latrans & $\mathrm{b}$ & (C) & $\begin{array}{l}\text { S. Forrest, unpublished } \\
\text { data }\end{array}$ \\
\hline \multicolumn{5}{|l|}{ Mustela nivalis (least } \\
\hline weasel) & V. vulpes & ... & $\mathrm{NC}$ & $\begin{array}{l}\text { Latham 1952; Macdonald } \\
\qquad 1977\end{array}$ \\
\hline M. nivalis & U. cineroargenteus & $\ldots$ & $\ldots$ & Latham 1952 \\
\hline \multicolumn{5}{|l|}{ Mustela putorius } \\
\hline (polecat) & V. vulpes & $\ldots$ & NC & Mulder 1990 \\
\hline \multicolumn{5}{|l|}{ Mustela vison (Ameri- } \\
\hline can mink) & A. lagopus & ... & $\mathrm{C}$ & $\begin{array}{l}\text { K. Frafjord, unpublished } \\
\text { data }\end{array}$ \\
\hline \multicolumn{5}{|l|}{ Nyctereutes procyono- } \\
\hline ides (raccoon dog) & C. lupus & ... & ... & $\begin{array}{l}\text { H. Okarma, unpublished } \\
\text { data }\end{array}$ \\
\hline N. procyonoides & L. $\operatorname{lyn} x$ & ... & ... & $\begin{array}{l}\text { H. Okarma, unpublished } \\
\text { data }\end{array}$ \\
\hline \multicolumn{5}{|l|}{ Otocyon megalotis } \\
\hline (bat-eared fox) & P. leo & $\ldots$ & (C) & Eloff 1984 \\
\hline O. megalotis & P. pardus & $\ldots$ & $\mathrm{C}$ & Mills 1990 \\
\hline O. megalotis & A. jubatus & $\ldots$ & $\mathrm{C}$ & Mills 1990 \\
\hline O. megalotis & H. brunnea & $\ldots$ & $\mathrm{C}$ & Mills 1990 \\
\hline P. leo & C. crocuta & $\mathrm{a}$ & $\ldots$ & Schaller 1972 \\
\hline P. leo & L. pictus & $\mathrm{b}$ & $\mathrm{C}$ & Pienaar 1969 \\
\hline P. leo & P. pardus & $\mathrm{a}$ & $\ldots$ & Schaller 1972 \\
\hline P. pardus & P. leo & $\mathrm{b}$ & $\mathrm{C}$ & $\begin{array}{l}\text { Kruuk and Turner 1967; } \\
\quad \text { Schaller } 1972\end{array}$ \\
\hline P. pardus & P. tigris & ... & $\mathrm{C}$ & $\begin{array}{l}\text { Seidensticker 1976; John- } \\
\text { singh } 1992\end{array}$ \\
\hline
\end{tabular}


Table A1 (Continued)

\begin{tabular}{|c|c|c|c|c|}
\hline Killed species & Killer species & $\begin{array}{l}\text { Age class } \\
\text { of victim }\end{array}$ & $\begin{array}{l}\text { Consumption } \\
\text { of victim }\end{array}$ & Sources \\
\hline P. tigris & C. alpinus & $\mathrm{b}$ & $\mathrm{C}$ & Schaller 1967 \\
\hline Procyon lotor (raccoon) & F. concolor & $\ldots$ & $\mathrm{C}$ & Maehr et al. 1990 \\
\hline P. lotor & C. latrans & $\cdots$ & $\mathrm{C}$ & $\begin{array}{l}\text { Clark et al. 1989; Hasbrouck } \\
\text { et al. 1992; Judson et al. } \\
\text { 1994; W. R. Clark, unpub- } \\
\text { lished data }\end{array}$ \\
\hline $\begin{array}{l}\text { Proteles cristatus } \\
\quad \text { (aardwolf) }\end{array}$ & P. pardus & $\ldots$ & $\mathrm{C}$ & Mills 1990 \\
\hline $\begin{array}{l}\text { Suricata suricatta } \\
\text { (suricate) }\end{array}$ & P. leo & $\ldots$ & NC & Eloff 1984 \\
\hline T. taxus & C. latrans & $\mathrm{a}$ & $\mathrm{C}$ & Rathbun et al. 1980 \\
\hline $\begin{array}{l}\text { Ursus americanus } \\
\text { (American black } \\
\text { bear) }\end{array}$ & C. lupus & $\mathrm{b}$ & $\mathrm{C}$ & $\begin{array}{l}\text { Rogers and Mech 1981; Ho- } \\
\text { rejsi et al. 1984; Paquet and } \\
\text { Carbyn } 1986\end{array}$ \\
\hline U. americanus & U. arctos & $\mathrm{b}$ & $\mathrm{C}$ & $\begin{array}{l}\text { Ross et al. 1988; Mattson et al. } \\
\text { 1992; Smith and Follmann } \\
1993\end{array}$ \\
\hline$U$. arctos & C. lupus & a & $\mathrm{C}$ & Ballard 1982 \\
\hline U. maritimus & C. lupus & $\ldots$ & $\mathrm{C}$ & Ramsay and Stirling 1984 \\
\hline Vulpes chama (cape fox) & P. pardus & $\ldots$ & $\mathrm{C}$ & Mills 1990 \\
\hline Vulpes macrotis (kit fox) & C. latrans & $\mathrm{b}$ & (C) & $\begin{array}{l}\text { O'Farrell 1984; Ralls and } \\
\text { White 1995; Cypher and } \\
\text { Spencer } 1998\end{array}$ \\
\hline V. macrotis & V. vulpes & $\mathrm{b}$ & $\mathrm{C}$ & $\begin{array}{l}\text { Ralls and White 1995; K. } \\
\text { Ralls, unpublished data }\end{array}$ \\
\hline Vulpes velox (swift fox) & C. latrans & $\ldots$ & $\ldots$ & Carbyn et al. 1994 \\
\hline V. velox & T. taxus & $\ldots$ & $\ldots$ & Carbyn et al. 1994 \\
\hline V. vulpes & C. latrans & $\mathrm{b}$ & (C) & Sargeant and Allen 1989 \\
\hline V. vulpes & C. lupus & $\ldots$ & (C) & $\begin{array}{l}\text { Mech 1970; A. Delibes, un- } \\
\text { published data; H. Okarma, } \\
\text { unpublished data }\end{array}$ \\
\hline V. vulpes & F. rufus & $\ldots$ & $\mathrm{C}$ & Petraborg and Gunvalson 1962 \\
\hline V. vulpes & L. pardinus & $\mathrm{b}$ & NC & $\begin{array}{l}\text { Palomares et al. 1996; F. Palo- } \\
\text { mares, unpublished data }\end{array}$ \\
\hline V. vulpes & $\begin{array}{l}\text { Lynx canadensis (North } \\
\text { American lynx) }\end{array}$ & $\mathrm{b}$ & $\mathrm{C}$ & Stephenson et al. 1991 \\
\hline V. vulpes & L. $\operatorname{lyn} x$ & $\mathrm{~b}$ & $\mathrm{C}$ & $\begin{array}{l}\text { Haglund 1966; Capt et al. } \\
\text { 1993; Sunde 1996; Liberg } \\
\text { 1997; Sunde and Kvam } \\
\text { 1997; H. Okarma, unpub- } \\
\text { lished data; J. Linnell, un- } \\
\text { published data }\end{array}$ \\
\hline V. vulpes & M. meles & $\mathrm{a}$ & NC & Neal and Cheeseman 1996 \\
\hline
\end{tabular}

Note: Information on the age class of the victim $(\mathrm{a}=$ the killer species only dispatches nonadult individuals of the victim species; $\mathrm{b}=$ the killer dispatches both young and adult individuals or only adults of the victim species) and whether they were consumed by the killer $(\mathrm{C}=$ consumed, $(\mathrm{C})=$ sometimes consumed, $\mathrm{NC}=$ not consumed $)$ are presented when known. Ellipses indicate that information is unknown. Species follow Wozencraft (1989). 


\section{Literature Cited}

Ackerman, B. B., F. G. Lindzey, and T. P. Hemker. 1984. Cougar food habits in southern Utah. Journal of Wildlife Management 48:147-155.

Bailey, E. P. 1992. Red foxes (Vulpes vulpes) as biological control agents for introduced arctic foxes (Alopex lagopus) on Alaskan Islands. Canadian Field-Naturalist 106:200-205.

Bailey, T. N. 1993. The African leopard: ecology and behavior of a solitary felid. Columbia Picture Press, New York.

Ballard, W. B. 1980. Brown bear kills gray wolf. Canadian Field-Naturalist 94:91.

1982. Gray wolf-brown bear relationships in the Nelchina Basin of South-Central Alaska. Pages 71-80 in F. H. Harrington and P. C. Paquet, eds. Wolves in the world. Noyes, Park Ridge, N.J.

Bender, E. A., T. J. Case, and M. E. Gilpin. 1984. Perturbation experiments in community ecology: theory and practice. Ecology 65:1-13.

Bengtsson, J., T. Fagerström, and H. Rydin. 1994. Competition and coexistence in plant communities. Trends in Ecology \& Evolution 9:246-250.

Berg, W. E., and R. A. Chesness. 1978. Ecology of coyotes in northern Minnesota. Pages 229-247 in M. Bekoff, ed. Coyotes: biology, behavior, and management. Academic Press, New York.

Bider, J. R., and P. G. Weil. 1984. Dog (Canis familiaris) killed by a coyote (Canis latrans) on Montreal Island, Quebec. Canadian Field-Naturalist 98:498-499.

Boles, B. K. 1977. Predation by wolves on wolverines. Canadian Field-Naturalist 91:68-69.

Boyd, D., and G. K. Neale. 1992. An adult cougar (Felis concolor) killed by gray wolves (Canis lupus) in Glacier National Park, Montana. Canadian Field-Naturalist 106: 524-525.

Boyd, D., and B. O'Gara. 1985. Cougar predation on coyotes. Murrelet 66:17.

Boyd, D., R. R. Ream, D. H. Pletscher, and M. W. Fairchild. 1994. Prey taken by colonizing wolves and hunters in the Glacier National Park area. Journal of Wildlife Management 58:289-295.

Burkholder, B. L. 1962. Observations concerning wolverine. Journal of Mammalogy 43:263-264.

Capt, S., F. Bernhart, U. Breitenmoser, C. BreitenmoserWürsten, H. Haller, M. Liberek, J. M. Vandel, and V. Herrenschmidt. 1993. Prédation du lunx (Lynx lynx) sur les ongulés sauvages et domestiques. Pages 85-91 in P. Migot and P. Stahl, eds. Actes du colloque prédation et gestion des prédateurs: Dourdan 1-2 Décembre, 1992. ONC-UNFDC, Paris.

Carbone, C., J. T. Du Toit, and I. J. Gordon. 1997. Feeding success in African wild dogs: does kleptoparasitism by spotted hyenas influence hunting group size? Journal of Animal Ecology 66:318-326.

Carbyn, L. N. 1982. Coyote population fluctuations and spatial distribution in relation to wolf territories in Riding Mountain National Park, Manitoba. Canadian Field-Naturalist 96:176-183.

Carbyn, L. N., H. J. Armbruster, and C. Mamo. 1994. The swift fox reintroduction program in Canada from 1983 to 1992. Pages 247-271 in M. Bowles and C. Whelan, eds. Restoration of endangered species. Cambridge University Press, Cambridge.

Caro, T. M. 1994. Cheetahs of the Serengeti Plains: group living in an asocial species. University of Chicago Press, Chicago.

Caro, T. M., and Laurenson, M. L. 1994. Ecological and genetic factors in conservation: a cautionary tale. Science (Washington, D.C.) 263:485-486.

Case, T. J., and M. E. Gilpin. 1974. Interference competition and niche theory. Proceedings of the National Academy of Sciences of the USA 71:3073-3077.

Cavallini, P. 1993. Spatial organization of the yellow mongoose (Cynictis penicillata) in a coastal area. Ethology Ecology and Evolution 5:501-509.

Chesemore, D. L. 1975. Ecology of the Arctic fox (Alopex lagopus) in North America: a review. Pages 143-163 in M. W. Fox, ed. The wild canids. Van Nostrand Reinhold, New York.

Clark, W. R., J. J. Hasbrouk, J. M. Kienzler, and T. Glueck. 1989. Vital statistics and harvest of an Iowa raccoon population. Journal of Wildlife Management 53: 982-990.

Creel, S., and N. M. Creel. 1996. Limitation of African wild dogs by competition with larger carnivores. Conservation Biology 10:526-538.

- 1998. Six ecological factors that may limit African dogs, Lycaon pictus. Animal Conservation 1:1-9.

Creel, S., N. M. Creel, J. A. Matovelo, M. M. A. Mtambo, E. K. Batamuzi, and J. E. Cooper. 1995. The effects of anthrax on endangered African wild dogs (Lycaon pictus). Journal of Zoology (London) 236:199-209.

Cypher, B. L., and K. A. Spencer. 1998. Competitive interactions between coyotes and San Joaquin kit foxes. Journal of Mammalogy 79:204-214.

Dekker, D. 1989. Population fluctuations and spatial relationships among wolves (Canis lupus), coyotes (Canis latrans), and red foxes (Vulpes vulpes) in Jasper National Park, Alberta. Canadian Field-Naturalist 103:261-264.

Delibes, M. 1980. El lince ibérico: ecología y comportamiento alimenticios en el Coto de Doñana, Huelva. Doñana Acta Vertebrata 7:1-128.

Diamond, J. 1986. Overview: laboratory experiments, field experiments, and natural experiments. Pages 3-22 in J. 
Diamond and T. J. Case, eds. Community ecology. Harper \& Row, New York.

Durant, S. M. 1998. Competition refuges and coexistence: an example from Serengeti carnivores. Journal of Animal Ecology 67:370-386.

Earle, M. 1987. A flexible body mass in social carnivores. American Naturalist 129:755-760.

Eaton, R. L. 1979. Interference competition among carnivores: a model for the evolution of social behavior. Carnivore (Seattle) 2:9-16.

Eloff, F. C. 1984. Food ecology of the Kalahari lion Panthera leo vernayi. Koedoe 27:249-258.

Erlinge, S. 1981. Food preference, optimal diet and reproductive output in stoats (Mustela erminea) in Sweden. Oikos 36:303-315.

Erlinge, S., G. Göransson, G. Högstedt, O. Liberg, J. Loman, I. Nilsson, T. Nilsson, T. von Schantz, and M. Sylven. 1982. Factors limiting numbers of vertebrate predators in a predator prey community. Transactions of International Congress of Game Biologists 14: 261-268.

Estes, J. A., and J. F. Palmisano 1974. Sea otters: their role in structuring nearshore communities. Science (Washington, D.C.) 185:1058-1060.

Fanshawe, J. H., and C. D. FitzGibbon. 1993. Factors influencing the hunting success of an African wild dog pack. Animal Behaviour 45:479-490.

Forrest, S. C., T. W. Clark, L. Richardson, and T. M. Campbell III. 1985. Black-footed ferret habitat: some management and reintroduction considerations. Wyoming BLM Wildlife Technical Bulletin 2:1-35.

Forrest, S. C., D. E. Biggins, L. Richardson, T. W. Clark, T. M. Campbell III, K. A. Fagerstone, and E. T. Thorne. 1988. Population attributes for the black-footed ferret (Mustela nigripes) at Meeteetse, Wyoming, 1981-1985. Journal of Mammalogy 69:261-673.

Frafjord, K., D. Becker, and A. Angerbjörn. 1989. Interactions between Arctic and red foxes in Scandinavia-predation and aggression. Arctic 42:354-356.

Fritts, S. H., and W. J. Paul. 1989. Interactions of wolves and dogs in Minnesota. Wildlife Society Bulletin 17: 121-123.

Fuller, T. K., and L. B. Keith. 1981. Non-overlapping ranges of coyotes and wolves in northeastern Alberta. Journal of Mammalogy 62:403-405.

Ginsberg, J. R., K. A. Alexander, S. Creel, P. W. Kat, J. W. Mcnutt, and M. G. L. Mills. 1995. Handling and survivorship of African wild dog (Lycaon pictus) in five ecosystems. Conservation Biology 9:665-674.

Gittleman, J. L. 1989. Carnivore group living: comparative trends. Pages 183-207 in J. L. Gittleman, ed. Carnivore behavior, ecology and evolution. Cornell University Press, Ithaca, N.Y.
Gorman, M. L., M. G. Mills, J. P. Raath, and J. R. Speakman. 1998. High hunting costs make African wild dogs vulnerable to kleptoparasitism by hyaenas. Nature (London) 391:479-481.

Haglund, B. 1966. Winter habits of the lynx (Lynx lynx L.) and wolverine (Gulo gulo L.) as revealed by tracking in the snow. Viltrevy 4:84-299.

Harrison, D. J., J. A. Bissonette, and J. A. Sherburne. 1989. Spatial relationships between coyotes and red foxes in eastern Maine. Journal of Wildlife Management 53: 181-185.

Hasbrouck, J. J., W. R. Clark, and R. D. Andrews. 1992. Factors associated with raccoon mortality in Iowa. Journal of Wildlife Management 56:693-699.

Hayes, R. D., and A. Baer. 1992. Brown bear, Ursus arctos, preying upon gray wolf, Canis lupus, pups at a wolf den. Canadian Field-Naturalist 106:381-382.

Hersteinsson, P., and D. W. Macdonald. 1992. Interspecific competition and the geographical distribution of red and arctic foxes (Vulpes vulpes) and (Alopex lagopus). Oikos 64:505-515.

Holt, R. D., and G. A. Polis. 1997. A theoretical framework for intraguild predation. American Naturalist 149: $745-764$.

Horejsi, B. L., G. E. Hornbeck, and R. M. Raine. 1984. Wolves (Canis lupus) kill female black bear (Ursus americanus) in Alberta. Canadian Field-Naturalist 98: 368-369.

Johnsingh, A. J. T. 1992. Prey selection in three large sympatric carnivores in Bandipur. Mammalia 56:517-526.

Johnson, D. H., A. B. Sargeant, and R. J. Greenwood. 1989. Importance of individual species of predators on nesting success of ducks in the Canadian Prairie Pothole region. Canadian Journal of Zoology 67:291-297.

Johnson, W. E., T. K. Fuller, and W. L. Franklin. 1996. Sympatry in canids: a review and assessment. Pages 189-218 in J. L. Gittleman, ed. Carnivore behavior, ecology, and evolution. Cornell University Press, Ithaca, N.Y.

Joshi, A. R., J. L. David Smith, and F. J. Cuthbert. 1995. Influence of food distribution and predation pressure on spacing behavior in palm civets. Journal of Mammalogy 76:1205-1212.

Judson, J. J., W. R. Clark, and R. D. Andrew. 1994. Postnatal survival of raccoons in relation to female age and denning behavior. Journal of Iowa Academy of Sciences 101:24-27.

Karanth, K. U., and M. E. Sunquist. 1995. Prey selection by tiger, leopard and dhole in tropical forest. Journal of Animal Ecology 64:439-450.

Kelly, M. J., M. K. Laurenson, C. D. FitzGibbon, D. A. Collins, S. M. Durant, G. W. Frame, B. C. R. Bertram, and T. M. Caro. 1998. Demography of the Serengeti 
cheetah population: the first twenty-five years. Journal of Zoology (London) 244: 473-488.

Knick, S. T. 1990. Ecology of bobcats relative to exploitation and a prey decline in southeastern Idaho. Wildlife Monographs 108:1-42.

Koehler, G. M., and M. G. Hornocker. 1991. Seasonal resource use among mountain lions, bobcats, and coyotes. Journal of Mammalogy 72:391-396.

Kruuk, H. 1972. The spotted hyena: a study of predation and social behavior. University of Chicago Press, Chicago.

- 1975. Functional aspects of social hunting in carnivores. Pages 119-141 in G. Baerands, C. Beer, and A. Manning, eds. Function and evolution of behavior. Oxford University Press, Oxford.

Kruuk, H., and M. Turner. 1967. Comparative notes on predation by lion, leopard, cheetah and wild dog in the Serengeti area, East Africa. Mammalia 31:1-27.

Lamprecht, J. 1978. On diet, foraging behavior and interspecific food competition of jackals in the Serengeti National Park, East Africa. Zeitschrift für Säugetierkunde 43:210-223.

- 1981. The function of social hunting in larger terrestrial carnivores. Mammal Review 11:169-179.

Latham, R. M. 1952. The fox as a factor in the control of weasel populations. Journal of Wildlife Management 16: 516-517.

Laurenson, M. K. 1994. High juvenile mortality in cheetahs (Acinonyx jubatus) and its consequences for maternal care. Journal of Zoology (London) 234:387-408.

- 1995. Implications of high offspring mortality for cheetah population dynamics. Pages 385-399 in A. R. E. Sinclair and P. Arcese, eds. Serengeti II: dynamics, management and conservation of an ecosystem. University of Chicago, Chicago.

Liberg, O. 1997. Lodjuret. Svenska Jägareförbundet, Uppsala, Sweden.

Lindström, E. R. 1989. The role of medium-size carnivores in the Nordic boreal forest. Finnish Game Research 46: 53-63.

Lindström, E. R., S. M. Brainerd, J. O. Helldin, and K. Overskaug. 1995. Pine marten-red fox interactions: a case of intraguild predation? Annales Zoologici Fennici 32:123-130.

Linhart, S. B., and W. B. Robinson. 1972. Some relative carnivore densities in areas under sustained coyote control. Journal of Mammalogy 53:880-884.

Litvaitis, J. A. 1992. Niche relations between coyotes and sympatric Carnivora. Pages 73-86 in A. H. Boer, ed. Ecology and management of the eastern coyote. Wildlife Research Unit, University of Brunswick, Canada.

Litvaitis, J. A., and D. J. Harrison. 1989. Bobcat-coyote niche relationships during a period of coyote population increase. Canadian Journal of Zoology 67:1180-1188.

Litvaitis, J. A., and R. Villafuerte. 1996. Intraguild predation, mesopredator release, and prey stability. Conservation Biology 10:676-677.

Macdonald, D. W. 1977. On food preferences in the red fox. Mammal Review 7:7-23.

Maehr, D., R. C. Belden, E. D. Land, and L. Wilkins. 1990. Food habits of panthers in southwest Florida. Journal of Wildlife of Management 54:420-423.

Major, J. T., and J. A. Sherburne. 1987. Interspecific relationships of coyote, bobcats, and red foxes in western Maine. Journal of Wildlife of Management 51:606-616.

Mattson, D. J., R. R. Knight, and B. M. Blanchard. 1992. Cannibalism and predation on black bears by grizzly bears in the Yellowstone ecosystem, 1975-1990. Journal of Mammalogy 73:422-425.

McLaren, B. E., and R. O. Peterson. 1994. Wolves, moose, and tree rings on Isle Royale. Science (Washington, D.C.) 266:1555-1558.

Mech, L. D. 1970. The wolf: the ecology and behavior of an endangered species. Natural History Press, New York.

Meffe, G. K., C. R. Carroll, and S. L. Pimm. 1994. Community-level conservation: species interaction, disturbance regimes, and invading species. Pages 209-236 in G. K. Meffe and C. R. Carrol, eds. Principles and conservation biology. Sinauer, Sunderland, Mass.

Menge, B. A. 1995. Indirect effects in marine rocky intertidal interactions webs: patterns and importance. Ecological Monographs 65:21-74.

Menge, B. A., and J. P. Sutherland. 1987. Community regulation: variation in disturbance, competition, and predation in relation to environmental stress and recruitment. American Naturalist 130:730-757.

Miller, S. D., G. C. White, R. A. Sellers, H. V. Reynolds, J. W. Schoen, K. Titus, V. G. Barnes, et al. 1997. Brown and black bear density estimation in Alaska using radiotelemetry and replicated mark-resight techniques. Wildlife Monographs 133:1-55.

Mills, M. G. L. 1990. Kalahari hyaenas. The comparative behavioural ecology of two species. Unwin Hyman, London.

1993. Social systems and behavior of the African wild dog (Lycaon pictus) and the spotted hyaena (Crocuta crocuta) with special reference to rabies. Onderstepoort Journal of Veterinary Research 60:405-409.

Mills, M. G. L., and H. C. Biggs. 1993. Prey apportionment and related ecological relationships between large carnivores in Kruger National Park. Symposium of Zoological Society of London 65:253-268.

Mills, M. G. L., and M. L. Gorman. 1997. Factors affecting the density and distribution of wild dogs in the Kruger National Park. Conservation Biology 11:1397-1406. 
Mondolfi, E., and R. Hoogesteijn. 1986. Notes on the biology and status of the jaguar in Venezuela. Pages 85-123 in S. D. Miller and D. D. Everett, eds. Cats of the world: biology, conservation and management. National Wildlife Federation, Washington, D.C.

Monson, D. H., and A. R. DeGange. 1995. Reproduction, preweaning survival, and survival of adult sea otters at Kodiak Island, Alaska. Canadian Journal of Zoology 73: 1161-1169.

Mulder, J. L. 1990. The stoat Mustela erminea in the Dutch dune region, its local extinction, and a possible cause: the arrival of the fox Vulpes vulpes. Lutra 33:1-21.

Neal, E., and C. Cheeseman. 1996. Badgers. Poyser, London.

Nowak, R. M. 1991. Walker's mammals of the world. Vol. 2. Johns Hopkins University Press, Baltimore.

Nowell, K., and P. Jackson. 1996. Wild cats. International Union for Conservation of Nature Publications. Burlington, Cambridge.

O'Farrell, T. P. 1984. Conservation of the endangered San Joaquin kit fox Vulpes macrotis mutica on the Naval Petroleum Reserves, California. Acta Zoologica Fennica 172:207-208.

Okarma, H. 1995. The trophic ecology of wolves and their predatory role in ungulate communities of forest ecosystems in Europe. Acta Theriologica 40:335-386.

Okarma, H., W. Jedrzejewski, K. Schmidt, R. Komalczyk, and B. Jedrzejewska. 1997. Predation of Eurasian lynx on roe deer and red deer in Bialowieza Primeval Forest, Poland. Acta Theriologica 42:203-224.

Olsson, O., J. Wirtberg, M. Andersson, and I. Wirtberg. 1997. Wolf (Canis lupus) predation on moose (Alces alces) and roer deer (Capreolus capreolus) in southcentral Scandinavia. Wildlife Biology 3:13-25.

Paine, R. T., J. T. Wootton, and P. D. Boersma. 1990. Direct and indirect effects of peregrine falcon predation on seabird abundance. Auk 107:1-9.

Palomares, F. 1993. Opportunistic feeding of the Egyptian mongoose, Herpestes ichneumon (L.), in southwestern Spain. Revue Ecologie (Terre Vie) 48:295-304.

Palomares, F., and M. Delibes. 1992. Some physical and population characteristics of Egyptian mongooses (Herpestes ichneumon L., 1758) in southwestern Spain. Zeitschrift für Säugetierkunde 57:94-99.

- 1994. Spatio-temporal ecology and behavior of European genets in southwestern Spain. Journal of Mammalogy 75:714-724.

Palomares, F., P. Gaona, P. Ferreras, and M. Delibes. 1995. Positive effects on game species of top predators by controlling smaller predator populations: an example with lynx, mongooses, and rabbits. Conservation Biology 9:295-305.

Palomares, F., P. Ferreras, J. M. Fedriani, and M. Delibes.
1996. Spatial relationships between Iberian lynx and other carnivores in an area of south-western Spain. Journal of Applied Ecology 33:5-13.

Palomares, F., P. Ferreras, A. Travaini, and M. Delibes. 1998. Coexistence between Iberian lynx and Egyptian mongooses: estimating interaction strength by structural equation modelling and testing by an observational study. Journal of Animal Ecology 67:967-978.

Paquet, P. C. 1991. Winter spatial relationships of wolves and coyotes in Riding Mountain National Park, Manitoba. Journal of Mammalogy 72:397-401.

1992. Prey use strategies of sympatric wolves and coyotes in Riding Mountain National Park, Manitoba. Journal of Mammalogy 73:337-343.

Paquet, P. C., and L. N. Carbyn. 1986. Wolves (Canis lupus) killing denning black bears (Ursus americanus) in the Riding Mountain National Park area. Canadian FieldNaturalist 100:371-372.

Paragi, T. F., W. N. Johnson, D. D. Katnik, and A. J. Magoun. 1996. Marten selection of postfire seres in the Alaskan taiga. Canadian Journal of Zoology 74: 2226-2237.

Petraborg, W. H., and V. E. Gunvalson. 1962. Observations on bobcat mortality and bobcat predation on deer. Journal of Mammalogy 43:430-431.

Pianka, E. R. 1988. Evolutionary ecology. 4th ed. Harper \& Row, New York.

Pienaar, U. 1969. Predator prey relationships among the larger mammals of the Kruger National Park. Koedoe 12:108-176.

Pimm, S. L. 1991. The balance of nature? University of Chicago Press, Chicago.

Polis, G. A. 1981. The evolution and dynamics of intraspecific predation. Annual Review of Ecology and Systematics 12:225-251.

Polis, G. A., and R. D. Holt. 1992. Intraguild predation: the dynamics of complex trophic interactions. Trends in Ecology \& Evolution 7:151-154.

Polis, G. A., C. A. Myers, and R. D. Holt. 1989. The ecology and evolution of intraguild predation: potential competitors that eat each other. Annual Review of Ecology and Systematics 20:297-330.

Pulliainen, E. 1965. Studies on the wolf (Canis lupus L.) in Finland. Annales Zoologici Fennice 2:215-259.

Raine, R. M. 1983. Winter habitat use and responses to snow cover of fisher (Martes pennati) and marten (Martes americana) in southeastern Manitoba. Canadian Journal of Zoology 61:25-34.

Ralls, K., and P. J. White. 1995. Predation on San Joaquin kit foxes by larger canids. Journal of Mammalogy 76: 723-729.

Ramsay, M. A., and I. Stirling. 1984. Interactions of wolves 
and polar bears in northern Manitoba. Journal of Mammalogy 65:693-694.

Rasa, O. A. E. 1986. Coordinated vigilance in dwarf mongoose family groups: the "watchman's song" hypothesis and the costs of guarding. Ethology 71:340-344.

Rathbun, A. P., M. C. Wells, and M. Bekoff. 1980. Cooperative predation by coyotes on badgers. Journal of Mammalogy 61:375-376.

Robinson, W. B. 1953. Population trends of predators and fur animals in 1080 station areas. Journal of Mammalogy 34:220-227.

Rogers, L. L., and L. D. Mech. 1981. Interaction of wolves and black bears in northeastern Minnesota. Journal of Mammalogy 62:434-436.

Rosatte, R. C. 1987. Striped, spotted, hooded, and hognosed skunk. Pages 599-613 in M. Novak, J. A. Baker, M. E. Obbard, and B. Malloch, eds. Wild furbearer management and conservation in North America. Ministry of Natural Resources, Ontario.

Rosenzweig, M. L. 1966. Community structure in sympatric carnivora. Journal of Mammalogy 47:602-612.

Ross, P. I., G. E. Hornbeck, and B. L. Horejsi. 1988. Late denning black bears killed by grizzly bear. Journal of Mammalogy 69:818-820.

Route, W. T., and R. O. Peterson. 1991. An incident of wolf (Canis lupus) predation on a river otter (Lutra canadensis) in Minnesota. Canadian Field-Naturalist 105:567-568.

Rudzinski, D. R., H. B. Graves, A. B. Sargeant, and G. L. Storm. 1982. Behavioral interactions of penned red and arctic foxes. Journal of Wildlife Management 46: 877-884.

Sargeant, A. B., and S. H. Allen. 1989. Observed interactions between coyotes and red foxes. Journal of Mammalogy 70:631-633.

Sargeant, A. B., R. J. Greenwood, J. L. Piehl, and W. B. Bicknell. 1982. Recurrence, mortality, and dispersal of prairie striped skunks (Mephitis mephitis) and implications to rabies epizootiology. Canadian Field-Naturalist 96:312-316.

Sargeant, A. B., S. H. Allen, and R. T. Eberhardt. 1984. Red fox predation on breeding ducks in midcontinent North America. Wildlife Monographs 89:1-41.

Sargeant, A. B., S. H. Allen, and J. O. Hastings. 1987. Spatial relations between sympatric coyotes and red foxes in North Dakota. Journal of Wildlife Management 51:285-293.

Sarrazin, F., and R. Barbault. 1996. Reintroduction: challenges and lessons for basic ecology. Trends in Ecology \& Evolution 11:474-478.

Schaller, G. B. 1967. The deer and the tiger. University of Chicago Press, Chicago.

- 1972. The Serengeti lion: a study of predator-prey relations. Wildlife Behavior and Ecology Series. G. B. Schaller, ed. University of Chicago Press, Chicago.

Schmidt, R. H. 1985. Controlling arctic fox populations with introduced red foxes. Wildlife Society Bulletin 13: 592-594.

Seidensticker, J. 1976. On the ecological separation between tigers and leopards. Biotropica 8:225-234.

Seidensticker, J., M. E. Sunquist, and C. Mcdougal. 1990. Conservation in developing countries: problems and prospects. Pages 415-423 in J. C. Daniel and J. S. Serrao, eds. Proceedings of the centenary seminar of the Bombay Natural History Society. Bombay Natural History Society, Oxford University Press, Bombay.

Smith, M. E., and E. H. Follmann. 1993. Grizzly bear (Ursus arctos) predation of a denned adult black bear (U. americanus). Canadian Field-Naturalist 107:97-99.

Smits, C. M. M., B. G. Slough, and C. A. Yasui. 1989. Summer food habits of sympatric arctic foxes, Alopex lagopus, and red foxes, Vulpes vulpes, in the northern Yukon Territory. Canadian Field-Naturalist 103: 363-367.

Soulé, M. E., D. T. Bolger, A. C. Alberts, J. Wright, M. Sorice, and S. Hill. 1988. Reconstructed dynamics of rapid extinctions of chaparral-requiring birds in urban habitat island. Conservation Biology 2:75-92.

Sovada, M. A., A. B. Sargeant, and J. W. Grier. 1995. Differential effects of coyotes and red foxes on duck nest success. Journal of Wildlife Management 59:1-9.

Stander, P. E. 1992. Foraging dynamics of lions in a semiarid environment. Canadian Journal of Zoology 70: 8-21.

Stephenson, R. O., D. V. Grangaard, and J. Burch. 1991. Lynx (Felis lynx) predation on red foxes (Vulpes vulpes) caribou (Rangifer tarandus) and dall sheep (Ovis dalli). Canadian Field-Naturalist 105:255-262.

Strauss, S. Y. 1991. Indirect effects in community ecology: their definition, study and importance. Trends in Ecology \& Evolution 6:206-210.

Suárez, F., M. Yanes, J. Herranz, and J. Manrique. 1993. Nature reserves and the conservation of Iberian shrubsteppe passerines: the paradox of nest predation. Biological Conservation 64:77-81.

Sunde, P. 1996. Foraging patterns of the European lynx (Lynx lynx) in Norway. Master's thesis. Københavns Universitet, Copenhagen.

Sunde, P., and T. Kvam. 1997. Diet patterns of Eurasian lynx Lynx lynx: what causes sexually determined prey size segregation? Acta Theriologica 42:189-201.

Tannerfeldt, M. 1997. Population fluctuations and life history consequences in the arctic fox. Ph.D. diss. Stockholm University, Stockholm.

Terborgh, J. 1992. Maintenance of diversity in tropical forests. Biotropica 24:283-292. 
Terborgh, J., and B. Winter. 1980. Some causes of extinction. Pages 119-133 in M. E. Soulé and B. A. Wilcox, eds. Conservation biology: an evolutionary-ecological perspective. Sinauer, Sunderland, Mass.

Theberge, J. B., and C. H. R. Wedeles. 1989. Prey selection and habitat partitioning in sympatric coyote and red fox populations, southwest Yukon. Canadian Journal of Zoology 67:1285-1290.

Thompson, I. D. 1994. Marten population in uncut and logged boreal forests in Ontario. Journal of Wildlife Management 58:272-280.

Thurber, J. M., R. O. Peterson, J. D. Woolington, and J. A. Vucetich. 1992. Coyote coexistence with wolves on the Kenai Peninsula, Alaska. Canadian Journal of Zoology 70:2494-2498.

Valverde, J. A. 1967. Estructura de una comunidad de vertebrados terrestres. Monografías Estación Biológica de Doñana 1:1-219.

Voigt, D. R., and B. D. Earle. 1983. Avoidance of coyotes by red fox families. Journal of Wildlife Management 47: 852-857.

Waage, J. K., and N. J. Mills. 1992. Biological control. Pages 412-430 in M. J. Crawley, ed. Natural enemies. Blackwell Scientific, Oxford.

White, P. A., and D. K. Boyd. 1989. A cougar (Felis concolor) kitten killed and eaten by gray wolves (Canis lu- pus) in Glacier National Park, Montana. Canadian Field-Naturalist 103:408-409.

White, P. A., and R. A. Garrott. 1997. Factors regulating kit fox populations. Canadian Journal of Zoology 75: 1982-1988.

White, P. A., K. Ralls, and R. A. Garrott. 1994. Coyote-kit fox interactions as revealed by telemetry. Canadian Journal of Zoology 72:1831-1836.

Wilcove, D. S. 1985. Nest predation in forest tracts and the decline of migratory songbirds. Ecology 66: 1211-1214.

Wootton, J. T. 1994. Predicting direct and indirect effects: an integrated approach using experiments and path analysis. Ecology 75:151-165.

Wozencraft, W. C. 1989. The phylogeny of the recent Carnivora. Pages 495-4535 in J. L. Gittleman, ed. Carnivore behavior, ecology and evolution. Chapman \& Hall, London.

Wright, S. J., M. E. Gompper, and B. DeLeon. 1994. Are large predators keystone species in Neotropical forests? the evidence from Barro Colorado Island. Oikos 71: 79-294.

Yonzon, P. B., and M. L. Hunter, Jr. 1991. Conservation of the red panda (Ailurus fulgens). Biological Conservation $57: 1-11$.

Associate Editors: John A. Byers Robert D. Holt 